\title{
Private equity and entrepreneurial management in management buy-outs
}

\author{
Hans Bruining $\cdot$ Ernst Verwaal $\cdot$ Mike Wright
}

Accepted: 11 October 2011/Published online: 29 October 2011

(C) The Author(s) 2011. This article is published with open access at Springerlink.com

\begin{abstract}
Critics claim that short-term profit orientation and high deal price strategies of private equity (PE) firms can negatively affect the ability of management buyouts to initiate and sustain entrepreneurial management. This study investigates this claim by comparing effects of majority PE backed and other buy-outs at different levels of financial leverage on post buy-out increases in entrepreneurial management. We propose that PE can be used as an organizational refocusing device that simultaneously increases entrepreneurial and administrative management. We find
\end{abstract}

H. Bruining - M. Wright

Rotterdam School of Management, Department of Strategic Management and Entrepreneurship, Erasmus University Rotterdam, Burgemeester Oudlaan 50, Room T07-47, 3062 PA Rotterdam, The Netherlands e-mail: jbruining@rsm.nl

M. Wright

e-mail: Mike.Wright@nottingham.ac.uk

E. Verwaal $(\bowtie)$

Research Institute in Economics and Management of Networks and Institutions, Queen's University Management School, Queen's University Belfast, Riddel Hall, 185 Stranmilles Road, Northern Ireland BT9 5EE, UK

e-mail: e.verwaal@qub.ac.uk

M. Wright

Centre for Management Buy-Out Research, Nottingham University Business School and Erasmus University, Jubilee Campus, Wollaton Road, Nottingham NG8 1BB, UK that majority PE-backed buy-outs significantly increase entrepreneurial management practices. Furthermore, the increased financial leverage positively affects administrative management in management buy-outs. However, the effect of high financial leverage is larger for majority PE-backed buy-outs. These results support the notion that PE firms help buyout companies develop ambidextrous organizational change: i.e. simultaneously develop entrepreneurial and administrative management practices. The findings have important implications for practitioners and policy makers.

Keywords Private equity - Entrepreneurship · Buyout

JEL Classifications $\quad \mathrm{G} 24 \cdot \mathrm{L} 26 \cdot \mathrm{G} 34$

\section{Introduction}

The international surge of private equity (PE) markets during the first decade of this century has been accompanied by a public debate about their effects, both positive and negative (Financial Services Authority 2006; PSE-Group in European Parliament 2007). PE firms have been presented, variously, as drivers of more efficient use of organizational resources, but also as asset strippers with adverse consequences for employees and other stakeholders that diminish chances 
for entrepreneurial growth of the firm. These concerns give rise to the need to evaluate the impact of $\mathrm{PE}$ governance on organizations, relevant stakeholders, and society as a whole.

A management buy-out (MBO) usually involves the acquisition of a divested division or subsidiary or of a private family owned firm by a new company in which the existing management takes a substantial proportion of the equity with substantial funding provided by banks. PE firms involved in MBOs seek to achieve returns on their investment through significant equity ownership, financial leverage, and strategic and operational monitoring and control of the companies in their investment portfolio (Wright and Bruining 2008). PE firms can be active investors through taking board seats and specifying contractual restrictions on the behavior of management which include detailed reporting requirements. Although recent attention has focused upon PE-backed buyouts, not all MBOs are PE-backed. Further, in some deals PE firms hold majority positions, giving them scope for ex-post contracting influence on the strategic policies of portfolio companies (Cotter and Peck 2001), while in others, especially former divisions and familyowned firms, they may have a less active role and take minority equity positions.

Despite the rhetoric of recent public debate, we can distinguish between two distinct PE management models. The traditional financial investor model creates value at the moment of the buyout through financial engineering and improves governance by introducing strong financial incentives in the portfolio firm (Cotter and Peck 2001). The other is a more active form of PE that, in addition to financial engineering and strong financial incentives, seeks enhanced value creation of the portfolio company by more active ownership. These PE firms monitor and influence the strategy and management practices of the buyout company through an active presence on the board (Nikoskelainen and Wright 2007).

Previous scholarly research has suggested both positive and negative effects of PE governance. PEbacked leveraged buyouts introduce enhanced monetary incentives for top management to create value by improving operating performance but do not report performance improvement resulting from entrepreneurial effort (Kaplan 1989; Smith 1990; Lichtenberg and Siegel 1990; Robbie and Wright 1995). Other studies show an increase in new product development, stronger engagement in entrepreneurial ventures, technological alliances, and $R \& D$ as major sources of improving financial performance post-MBO (Bull 1989; Green 1992; Wright et al. 1990; Zahra 1995; Bruining and Wright 2002). Lerner et al. (2008) confirm that PE firms create both productive and innovative growth. The experience and industry specialization of PE firms also seems to be significantly associated with higher performance (Cressy et al. 2007; Meuleman et al. 2009).

Other studies show that the effect of high debt levels associated with PE governance set severe resource constraints post-MBO that can be harmful to entrepreneurial performance (Andrade and Kaplan 1998; Campello 2003). In general, PE firms tend to increase leverage as one source of value creation. However, previous research did not separate the effect of leverage from the potential positive effects associated with PE governance. In practice, these effects may be confounded, because PE firms can simultaneously increase leverage and stimulate entrepreneurial management practices. Research that ignores these confounding effects may lead to incorrect conclusions about assumed relationships. A second shortcoming of previous research is that it did not adopt conceptually grounded measures of entrepreneurial and administrative management dimensions. Therefore, the extant buy-out literature does not provide an unambiguous answer concerning the role of PE governance in postMBO performance (Cumming et al. 2007; Kaplan and Strömberg 2009).

Our study suggests several contributions to the buyout and PE literature to address these gaps. First, using Stevenson's (1983) validated conceptualization of entrepreneurial and administrative management (Brown et al. 2001) we provide the first detailed direct examination of the relative importance of entrepreneurial versus administrative management practices after the buy-out. Second, we extend insights regarding the importance of considering the heterogeneity of financing types in buyouts for the strategic focus of the firm by exploring the role of PE firms in buy-out governance. Third, and of particular relevance for the policy debate, we reveal that majority PE investors can increase both entrepreneurial and administrative management, depending on the level of financial leverage of the buy-out firm. These findings have important implications for theory and for policy makers and practitioners, and help to obtain a more detailed 
understanding of the changes taking place post buyout. In particular, management buyouts may involve ambidextrous approaches by PE firms.

\section{Literature review and hypotheses}

\subsection{Entrepreneurial and administrative management}

Entrepreneurial management is a set of opportunitybased management practices covering a continuum of firm behavior that can help organizations remain vital and contribute to firm and societal level value creation and competitiveness (Stevenson and Gumpert 1985). At one end of the continuum, entrepreneurial management is an outward opportunity-seeking approach to management without regard to resources currently controlled. At the other end, administrative management is a more inward-oriented management approach toward resources and competcompetenciesare currently controlled (Table 1). The six dimensions of this model are: strategic orientation, resource orientation, management structure, reward philosophy, growth orientation, and entrepreneurial culture (Brown et al. 2001). Changes in entrepreneurial management are a result of changes in one or more dimensions of this model.

An organization can lean toward either administrative or entrepreneurial management. We choose the entrepreneurial management model because we believe that the six dimensions of the model are appropriate to cover conceptually the expected changes following a buyout.

The renewed ownership structure and the increased leverage of the buy-out firm can lead to changes in the way the company is led by management (Robbie and Wright 1996), or to changes in its strategic and growth orientation (Phan and Hill 1995), its organizational culture (Green 1992), and the allocation of resources and choice of incentives (Reid 1996). Especially in divisional buyouts, the strategic orientations of managers are initially motivated by the market opportunities they see in the business setting that they were unable to pursue as former directors of a subsidiary (Wright et al. 2001a). After the buyout, the directors are spurred to allocate resources to operations with the strongest cash flow and to eliminate unprofitable operations (Jensen 1993; Wright et al. 1994). Management structures after buyout tend to become more decentralized, with fewer management layers, thus enhancing the speed of decision-making and leaving room for managers and workers to adapt freely to changing circumstances (Phan and Hill 1995). Monitoring and rewarding by the PE firm will stimulate a post-MBO philosophy based on creating value for the firm in terms of improving efficiency (Harris et al. 2005) and/or innovative growth (Bruining and Wright 2002; Meuleman et al. 2009). Pre-MBO, divisional buyout managers may find growth-oriented strategies are limited by headquarters; after the buyout, these barriers may be removed. Managers may be freed from bureaucratic limitations set by the former parent company, which opens up opportunities to carry out

Table 1 Stevenson's conceptualization of entrepreneurial management (Brown et al. 2001)

\begin{tabular}{lll}
\hline Entrepreneurial focus & Conceptual dimensions & Administrative focus \\
\hline $\begin{array}{l}\text { Driven by perception of opportunity } \\
\begin{array}{l}\text { Many stages with minimum exposure } \\
\text { at each stage }\end{array}\end{array}$ & $\leftarrow$ Strategic orientation $\rightarrow$ & $\begin{array}{c}\text { Driven by controlled resources } \\
\text { A single stage with complete } \\
\text { commitment out of decision }\end{array}$ \\
$\begin{array}{l}\text { Episodic use or rent of required } \\
\text { resources }\end{array}$ & $\leftarrow$ Resource orientation $\rightarrow$ & $\begin{array}{c}\text { Ownership or employment of required } \\
\text { resources }\end{array}$ \\
$\begin{array}{l}\text { Flat, with multiple informal networks } \\
\text { Based on value creation }\end{array}$ & $\leftarrow$ Management structure $\rightarrow$ & $\begin{array}{c}\text { Hierarchy } \\
\text { Rapid growth is top priority; risk } \\
\text { accepted to achieve growth }\end{array}$ \\
$\begin{array}{l}\text { Promoting broad search for } \\
\text { opportunities }\end{array}$ & $\leftarrow$ Reward philosophy $\rightarrow$ & $\begin{array}{c}\text { Based on responsibility and seniority } \\
\text { Safe, slow, steady }\end{array}$ \\
& $\leftarrow$ Entrepreneurial culture $\rightarrow$ & Opportunity search restricted by \\
resources controlled; failure \\
punished
\end{tabular}


their own policy and plans (Green 1992; Wright et al. 2001a; Zahra 1995).

We use the entrepreneurial and administrative management model to formulate hypotheses relating to how the increase in financial leverage and the majority equity of PE firms post-buyout may affect behavior toward administrative or the entrepreneurial management.

\subsection{Hypotheses development}

The level of debt increases substantially after MBO, enabling PE investors and management to control most of the stock. Concentrated ownership provides PE firms with the ability to monitor and control the strategy of the buyout target firm through their active presence on the board (Nikoskelainen and Wright 2007). According to Cotter and Peck (2001), LBO transactions are more likely to be financed with less short-term and/or senior debt and are subsequently less likely to default when buyout specialists control most of the post-LBO equity. Furthermore, they also find evidence of active monitoring of management by buyout specialists through greater board representation on smaller boards.

Following Cotter and Peck (2001) we define a majority PE position as owning 50\% or more of the voting common stock. Majority and minority $\mathrm{PE}$ investors use their effort to encourage the buy-out management team to focus on cash flow and activate its strategic thinking. However the governance of a minority $\mathrm{PE}$ investor is more defensive in nature compared with the majority PE investor. Concentrated ownership in PE firms means an incentive to take action (Cotter and Peck 2001). For example, a majority PE investor can install a supervisory board when this is seen as necessary to add value to the firm, or to counterbalance possible gaps in knowledge in the management board of the company in which they have invested. They can be more "hands-on" by taking decisions to replace the incumbent management and appoint new managers. This may bring the buyout firm back on track faster with innovative products/services than under the former management (Bruining and Wright 2002). Such intervention may be especially necessary when unexpected situations occur and the majority PE investor seeks value creation during the holding period by active ownership. We argue that this offensive stance of a majority PE investor is usually difficult for a minority PE investor. The minority PE investors can use their voting block for some decisions documented in the shareholders' agreement, for example to hold up the PE's approval of expansion/ growth plans. This is a more defensive way of acting. Hence, as contracts are incomplete, minority PE investors may face serious limitations in the adaptation of policies in cases of unexpected changes (Williamson 1991). Majority PE investors hold such ex-post contracting rights because strategic decisions of the portfolio company generally need to be approved by the investor, which is the owner of the majority of authorised shareholder votes. Both types of PE firm behavior affect the buy-out firm and may have positive effects on post-MBO performance. However, the minority PE investor generally trusts the disciplining effect of debt and monetary incentives to motivate managers to maximize the value of the firm, whereas the majority PE investor uses, in addition to these mechanisms, their active presence in the supervisory board as a financial and strategic control of the buyout firm and thus as a substitute for debt as a disciplining device (Cotter and Peck 2001). At the same time, both types of investor want to retain their reputation as a good borrower to ensure access to debt capital. In contrast, investors such as management and banks have different incentives to improve post-MBO firm value. For example, through decisions about allocation of firm's resources, managers can transfer wealth from debt holders to themselves, which results in more conflicts between shareholders and debt holders than in cases of private equity ownership. Commercial banks do not have stock ownership in MBO firms and thus have less incentive to monitor MBO management to increase the equity value of the firm, rather they prefer tighter debt terms.

Nikoskelainen and Wright (2007) found that returns are driven by the size of the buy-out firm and by acquisitions after the buyout. This supports the importance of incentives for entrepreneurial management to realize growth opportunities. Divisional buyouts are initiated if managers recognize growth opportunities that were constrained by the former parent company (Wright et al. 2001a). PE firms are keen to select divisions which are peripheral to the parent's strategy and which have to catch up with investment. Divisional buyouts are associated with refocusing of the strategic activities of the firm, especially for deals involving listed corporations and 
firms in distress (Robbie et al. 1993; Wiersema and Liebeskind 1995). Evidence from the Netherlands, USA and UK in the 1980s shows that other types of buyout, for example going private and buyouts from private firms, are also followed by significant increases in new product development and other aspects of corporate entrepreneurship (Bull 1989; Green 1992; Wright et al. 1992; Zahra 1995). Scholes et al. (2010) report strategy changes after family firm buyouts that offer large potential for growth and efficiency gains if the founder is still involved in the business on buyout. Divisional buyouts reduce trading dependence on the former parent by introducing new products they had previously been prevented from developing and by finding new customers (Wright et al. 1990; Meuleman et al. 2009).

The firm can be viewed as an organizational device to establish and implement a particular cognitive focus (Nooteboom 2009). However, firms often need a complementary and distant cognitive focus in order to refocus their cognitive model. After the buy-out, the firm may need to go through a transition of cognitive refocusing and may utilize the different and complementary cognition of the majority PE investor to achieve this. Majority PE investors contribute to the development of a new cognitive focus by assisting in new ventures to broaden market focus and, by having industrial experience, to assess investment in product development (Bruining and Wright 2002). They also contribute positively to the development of management control systems that facilitate strategic change (Jones 1992; Bruining et al. 2004). Lerner et al. (2008) report that buy-outs increase patent citations after PE firm investment with the quantity of patenting remaining unchanged.

Thus, we expect that PE firms with majority equity stakes in MBOs combine the advantages of changing the capital structure and board governance with strong involvement in strategic decision making and operations (Jensen 2006). PE firms need majority stakes to achieve the specialization and control required for an active governance role that helps buy-out firms to develop and implement a new cognitive focus that prepares the firm for entrepreneurial growth. Without a majority stake, the PE firm is more likely to focus on financial engineering and selective changes in governance, and take a more passive governance role similar to that of banks. Hence we formulate:
Hypothesis 1 Majority PE ownership in a management buyout is positively (negatively) related to entrepreneurial management (administrative management).

Debt levels normally increase after buy-out, leading to a reduction of agency costs and an increase in firm value through improved operating efficiency. Jensen (1986, 1989) predicts positive effects on business performance from higher debt levels post-MBO because incumbent managers take better decisions than before. Before the divisional buyout, the large and complex parent firm frequently lacks appropriate control and incentive mechanisms. Concentrated ownership and active involvement by the PE investor on the board combined with realignment of incentives makes close monitoring of the business and controlling of the strategy possible, with consequently improved performance (Hite and Vetsuypens 1989). Berger and Bonaccorsi di Patti (2006) support this view, and found that high leverage or a low equity/asset ratio reduces agency costs of outside equity and increases firm value by constraining or encouraging managers to act more in the interests of shareholders. From a corporate governance perspective, debt is a disciplining device. Investors are keen on information that signals the ability of the firm to meet its interest payments.

Some studies support this agency perspective (Kaplan 1989; Cotter and Peck 2001) and report a positive relationship between increased financial leverage, realignment and operating performance of buyout companies. Other studies provide evidence of cost cutting, improved margins, and efficiency postMBO (Lichtenberg and Siegel 1990; Desbrières and Schatt 2002; Harris et al. 2005) or show reductions in capital requirements after a buy-out (Easterwood et al. 1989; Singh 1990; Smith 1990; Long and Ravenscraft 1993). Robbie and Wright (1995) argue that in smaller buyouts debt commitment and covenants are important triggers for corrective action. However, the agency argument does not appear to receive strong support for public to private buyouts (Halpern et al. 1999; Opler and Titman 1993; Weir et al. 2005; Renneboog et al. 2007).

Evidence regarding the effect of high leverage on $\mathrm{R} \& \mathrm{D}$ expenses is at best mixed. Long and Ravenscraft (1993), for example, show that R\&D intensity falls by 40 percent compared with pre-buyout levels as a result of increased leverage, whereas Lichtenberg and Siegel 
(1990) did not find evidence that the $\mathrm{R} \& \mathrm{D} /$ sales ratio declined post-MBO. Long and Ravenscraft (1993) also find that R\&D intensive LBO firms outperform their non-LBO peers and LBOs that do not have any $R \& D$ expenditure.

Being strongly committed to servicing debt obligations can imply that a significant portion of the firm's future cash flow is not invested in new business opportunities nor distributed to the owners, but will only be used to reduce debt. Rappaport (1990) emphasizes that high debt levels form new resource constraints post-MBO and may be harmful for the survival of the company and thus for entrepreneurial management. Andrade and Kaplan (1998) find that the primary cause of financial distress is high leverage, with poor firm and industry performance as less important causes. Post-MBO debt levels generally increase significantly (Wright et al. 1991; Acharya et al. 2007). Therefore we formulate:

Hypothesis 2 Increased financial leverage in a management buyout is negatively (positively) related to entrepreneurial management (administrative management).

Entrepreneurial management, driven by a broad search for opportunities, involves development of new markets, new designs, and new channels of distribution. These variables measure business performance in terms of growth by utilizing the upside potential in new products and markets of the company in which they have invested. In contrast, administrative management is driven by opportunity search restricted by the resources controlled and involves expanding existing markets, established designs, and increased efficiency of existing distribution channels. These variables measure business performance by improving efficiency through controlling the downside risks of existing operations. Both entrepreneurial growth and administrative efficiency are needed on a sustainable level because performance is a joint function of explorative search and development and efficient exploitation of organizational capabilities (March 1991).

The occasion of a buyout is an appropriate moment to rethink the existing product portfolio and the longterm adaptations needed. These fundamental considerations emphasize the role of targets or aspiration levels in regulating allocation of effort to search (March 1988) and take place in buyouts stemming from different sources. In the context of divisional buyouts, lifting of the constraints imposed by the former parent's control enables renewal of aspirations of the new owners, which is a significant factor that drives the strategy and organization and their respective changes post-MBO. In the context of buyouts of family owned firms, changes in the marketplace require new leadership and adaptation of strategies to facilitate transition to the new growth phase (Wright et al. 2001b; Scholes et al. 2010). In general the new owner-managers view the buy-out as an opportunity to free them from control by the parent firm or by the overly conservative founder and implement the course of action they think is best for the company. The focus of our paper is on the private equity investor that exercises ownership by monitoring and controlling the strategy of the buyout company through active presence on the board (Nikoskelainen and Wright 2007). As a minority private equity investor it is more difficult to be more hands-on and take an active stance toward growth opportunities. Therefore we expect that a private equity investor before deciding to take a majority equity stake seriously reflects on his contribution, on the supervisory board, to value creation. He must be convinced he is able to fill a gap in management knowledge or provide additional influence through networks which are essential if the company in which the investment has been made is to exploit entrepreneurial opportunities.

Because MBOs typically involve increased levels of external funding, the PE firms need stable business relationships with the banks as they supply the necessary financial resources. Debt holders prefer cash flow rights associated with earnings and debt repaid ahead of common shareholders in case of bankruptcy, and are reluctant to engage in risky projects. Therefore, buyouts with very high debt levels may face initial pressure to improve administrative management practices post-MBO to improve the efficiency of existing operations, and thus reduce the debt level, before engaging in entrepreneurial management to realize growth opportunities. The literature (Wright et al. 2000) indicates that the debt side of buyout firm financing will trigger managerial cognition, whereas the ownership or incentive side will activate entrepreneurial cognition. Therefore we argue that majority PE investors will strengthen this managerial cognition by improving administrative management practices such as accounting information management, cash flow management (Mitchell, Reid 
and Terry 1997), and capital allocation processes, including elimination of unprofitable operations (Jensen 1993; Wright et al. 1994). Hence, with very high debt levels the focus of the majority PE investor will be first on administrative management to enhance efficiency in order to reduce the risks of debt. The more efficient monitoring and strategic control by the majority PE investors increase administrative management and thus reduce entrepreneurial management. Therefore we formulate:

Hypothesis 3 Majority PE ownership strengthens the positive relationship between increased financial leverage and administrative management.

\section{Methods}

\subsection{Data collection}

Data were collected from Dutch firms that underwent a buyout during 1996-2004. Although recent attention has focused solely upon PE-backed buyouts, many management buyouts are not PE-backed (CMBOR 2010). To test our hypotheses, we need to examine both $\mathrm{PE}$ and non-PE-backed management buyouts. The complete population of CEOs of 600 Dutch buyout firms (PE-backed and not PE-backed buyouts) in the period 1996-2004 were contacted by the Centre for Management Buyout Research (CMBOR) and 108 CEOs (18\%) responded. All respondents were involved in the buyout both before and after the MBO. The names and addresses were sought from Reach, an online database of Bureau Van Dijk. The survey took place in March 2006 and was sent by post. Three weeks after the mailings a reminder was sent followed by telephone calls to companies two weeks later. Extensive information was gathered and analyzed from the CMBOR database to survey a number of characteristics, for example vendor source of the buy-out, type of financier, debt level, and how entrepreneurial management developed after the MBO-deal took place compared with the year before the MBO.

Our sample contained approximately 35\% observations where buyout firms were not PE-backed. A potential problem in our study is that buyouts backed by PE may differ in measured and unmeasured characteristics from firms which are not PE-backed. To assess potential selection bias in PE backing, a
Heckman selection bias test was used. First, we performed logistic regression on PE ownership to construct the Heckman selection bias control factor (lambda) and this estimation demonstrated sufficient explanatory power (Nagelkerke $R^{2}=0.469$ ). The control factor lambda captures the probability of PE ownership as a function of firm size, industry characteristics and buyout type. Information on unobserved characteristics is not available in regression estimates; however, this information is available in the residuals of the probit analysis which we used to calculate lambda. The procedure can therefore effectively mitigate sample-selection bias.

The control factor was then added to the OLS model estimate of entrepreneurial management. The selection bias factor was not significant, indicating that unobserved factors do not have a significant effect on the estimates. We repeated the procedure with the control factor lambda that captures the probability of PE majority ownership, which also produced an insignificant selection bias factor. Finally, we checked for clustering in the data by looking at whether the same PE investors backed multiple firms. Although we cannot rule out clustering completely, we conclude that more than half of the PE firms do not back multiple firms in the dataset.

We tested the representativeness of the sample with regard to the source of the MBO transaction and found no significant differences. In addition, comparison of results from early respondents with those from late respondents (median split) revealed no significant difference $(P>.69)$, which suggests no problem with response bias in the survey data (Armstrong and Overton 1977).

We examined reliability issues associated with single-informant data by surveying additional senior managers of randomly selected responding firms. Seven firms provided additional informants. We calculated an interrater agreement score $\left(r_{\mathrm{wg}}\right)$ for each variable (James et al. 1993). The median interrater agreement ranged from 0.73 to 0.87 , suggesting adequate agreement for aggregation as it exceeds the generally accepted cut-off point of 0.60 (Glick 1985). Furthermore, intra-class correlations suggest strong interrater reliability, as all correlations between the relevant variables were significant at the 0.01 level (Jones et al. 1983).

We also checked for common method bias by performing Harman's one-factor test on the self- 
reported items of the latent models included in our study. The hypothesis of one general factor underlying the relationships was rejected $(P<0.001)$. In addition, we found four factors and the first factor did not account for most of the variance.

\subsection{Variables}

\subsubsection{Dependent variables}

We use the operationalization of Stevenson's conceptual dimensions of entrepreneurial management developed and validated by Brown et al. (2001) as shown in Table 2. The items of the ten-point entrepreneurial management scale are of the forced types, with pairs of statements representing opposite ends of the promoter/trustee continuum. This bipolar scale implies that high scores on entrepreneurial management are low scores on administrative management, and vice versa. Next we validated the Stevenson's dimensions by using factor analyses using varimax rotation. The results confirmed the findings of Brown et al. (2001) and showed six independent dimensions (Cronbach alpha $>0.66$ ), each of which independently contributes to the formative construct entrepreneurial management, which indicates the degree of entrepreneurial management. The dependent variable in our study is measured as the post-buyout increase in entrepreneurial management.

To examine the development of entrepreneurial and administrative management, we performed a onesample $t$-test on the post buyout change in the entrepreneurial management dimensions (Table 3). For all of the dimensions we asked for the incremental change after the buyout at the time of the survey compared with the situation before the buyout. The point of indifference is represented on a ten-point scale by 5.5 . The mean difference per dimension reveals a modest but significant increase in entrepreneurial management after the buyout, except for the dimensions management structure and entrepreneurial culture. The highest increase (1.42) is for the strategic orientation dimension followed by reward philosophy (0.86), growth orientation (0.57), and resource orientation (0.31). Entrepreneurial culture shows a decrease in entrepreneurial management $(-1.0)$ and becomes more administrative in nature than before the MBO.
The only dimension that showed no significant change is the management structure.

\subsubsection{Independent variables}

We measure financial leverage after buy-out as the ratio of debt (short and long debt)/total assets (balance sheet total) after the MBO.

Our PE measure is defined as: Does PE possess most of the authorized voting shares in your company? We expect that minority PE investments will not be in a position to independently influence the decisions of the buy-out company. Because contracts are incomplete, minority PE investors may face serious limitations in their adaptive coordination routines with the portfolio company in cases of unexpected changes (Williamson 1991). Majority PE investors hold ex-post contracting rights, because strategic decisions of the portfolio company must generally be approved by the investor which holds most of the authorised shareholder votes.

\subsubsection{Control variables}

As the nature and extent of entrepreneurial and innovative opportunities may vary by sector, we control for differences in industry, distinguishing dummy variables for trade, manufacturing, and services, and a residual category "other" which is used as the baseline category. We also control for the deal price premium (measured as the price paid for the firm relative to the market price) because this may reflect expected entrepreneurial opportunities. PE research has indicated that larger deals are more likely to be majority owned by PE firms and to involve greater restructuring activities. Therefore, we control for portfolio firm size (measured as the number of fulltime employees at the time of the buyout). Introducing entrepreneurial and innovative actions is likely to take time, possibly longer than administrative management changes. Therefore, we control for the duration of the buy-out at the time of the study (measured as the time since the buyout). Finally, we included the source of the buyout (divisional or family buyout versus other sources of buyouts) to control for the level of preMBO entrepreneurial focus of the buyout (Wright et al. 2000). Previous research indicates that the level of entrepreneurial management is relatively low 
Table 2 Operationalization of entrepreneurial management (Brown et al. 2001)

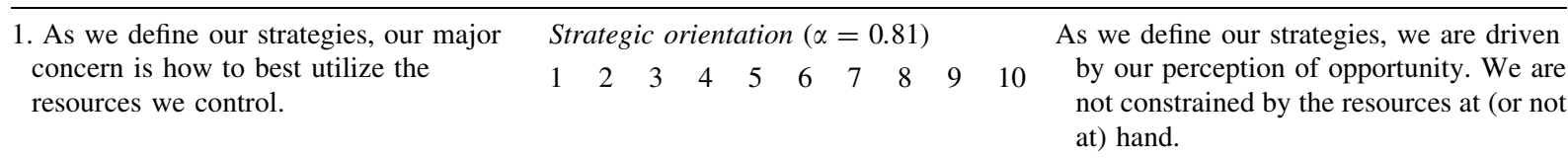

2. We limit the opportunities we pursue on $\begin{array}{llllllllllll}1 & 2 & 3 & 4 & 5 & 6 & 7 & 8 & 9 & 10 & \text { Our fundamental task is to pursue }\end{array}$ the basis of our current resources. opportunities we perceive as valuable and then to acquire the resources to exploit them.

3. The resources we have significantly affect our business strategies.

1. Because we do not need resources to commence the pursuit of an opportunity, our commitment of resources may be in stages.

2. All we need from resources is the ability to use them.

5. We like to employ resources that we borrow or rent.

6. In exploiting opportunities, having the idea is more important than just having the money.

1. We prefer tight control of funds and operations by means of sophisticated control and information systems.

2. We strongly emphasize getting things done by following formal processes and procedures.

3. We strongly emphasize holding to tried and true management principles and industry norms.

4. There is strong insistence on a uniform management style throughout the firm.

5. There is strong emphasis on getting line and staff personnel to adhere closely to their formal job descriptions.

1. Our employees are evaluated and compensated on the basis of their responsibilities

2. Our employees are evaluated and compensated on the basis of their responsibilities.

3. An employee's standing is based on the amount of responsibility s/he has.

4. It is generally known throughout the firm that growth is our top objective.

5. It is generally known throughout the firm that our intention is to grow as large and as rapidly as possible.

1. We have many more promising ideas than we have time and the resources to pursue them. $\begin{array}{lllllllllll}1 & 2 & 3 & 4 & 5 & 6 & 7 & 8 & 9 & 10 & \text { Opportunities control our business }\end{array}$ strategies.

Resource orientation $(\alpha=0.77)$

$\begin{array}{llllllllll}1 & 2 & 3 & 4 & 5 & 6 & 7 & 8 & 9 & 10\end{array}$

Because our objective is to use our resources, we will usually invest heavily and rapidly. ( $\mathrm{R})$

$\begin{array}{lllllllllll}1 & 2 & 3 & 4 & 5 & 6 & 7 & 8 & 9 & 10 & \text { We prefer to totally control and own the }\end{array}$ resources we use. $(\mathrm{R})$

$\begin{array}{llllllllllll}1 & 2 & 3 & 4 & 5 & 6 & 7 & 8 & 9 & 10 & \text { We prefer to only use our own resources in }\end{array}$ our ventures. $(\mathrm{R})$

$\begin{array}{llllllllllll}1 & 2 & 3 & 4 & 5 & 6 & 7 & 8 & 9 & 10 & \text { When using opportunities, access to money }\end{array}$ is more important than just having the idea. (R)

Management structure $(\alpha=0.80)$

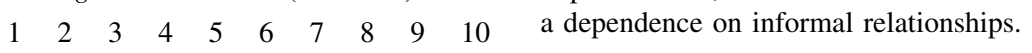

$\begin{array}{lllllllllll}1 & 2 & 3 & 4 & 5 & 6 & 7 & 8 & 9 & 10 & \text { We strongly emphasize getting things done }\end{array}$ even if this means disregarding formal procedures.

$\begin{array}{lllllllllll}1 & 2 & 3 & 4 & 5 & 6 & 7 & 8 & 9 & 10 & \text { We strongly emphasize adapting freely to }\end{array}$ changing circumstances without much concern for past practices.

$\begin{array}{lllllllllll}1 & 2 & 3 & 4 & 5 & 6 & 7 & 8 & 9 & 10 & \text { Managers' operating styles are allowed to }\end{array}$ range freely from very formal to very informal.

$\begin{array}{lllllllllll}1 & 2 & 3 & 4 & 5 & 6 & 7 & 8 & 9 & 10 & \text { There is a strong tendency to let the }\end{array}$ requirements of the situation and the personality of the individual dictate proper job behavior.

Reward philosophy $(\alpha=0.73)$

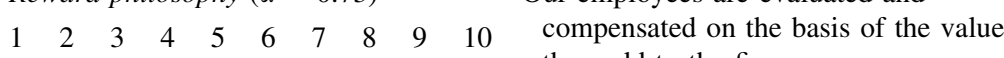
they add to the firm.

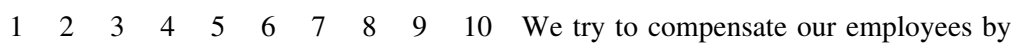
devising ways they can benefit from the increased value of the firm.

$\begin{array}{lllllllllll}1 & 2 & 3 & 4 & 5 & 6 & 7 & 8 & 9 & 10 & \text { An employee's standing is based on the }\end{array}$ value s/he adds.

Growth orientation $(\alpha=0.71)$

$\begin{array}{llllllllll}1 & 2 & 3 & 4 & 5 & 6 & 7 & 8 & 9 & 10\end{array}$

Growth is not necessarily our top objective.

Long-term survival may be at least as important. (R)

$\begin{array}{lllllllllll}1 & 2 & 3 & 4 & 5 & 6 & 7 & 8 & 9 & 10 & \text { It is generally known throughout the firm }\end{array}$ that steady and sure growth is the best way to expand. (R)

Entrepreneurial culture $(\alpha=0.66)$

We find it difficult to find a sufficient $\begin{array}{lllllllllll}1 & 2 & 3 & 4 & 5 & 6 & 7 & 8 & 9 & 10 & \text { number of promising ideas to utilize all of }\end{array}$ our resources. (R) 
Table 2 continued

\begin{tabular}{|c|c|c|c|c|c|c|c|c|c|c|c|}
\hline $\begin{array}{l}\text { 2. Changes in the society-at-large often } \\
\text { give us ideas for new products and } \\
\text { services. }\end{array}$ & 1 & 2 & 3 & 4 & 5 & 6 & 7 & 8 & 9 & 10 & $\begin{array}{l}\text { Changes in society-at-large seldom lead to } \\
\text { commercially promising ideas for our } \\
\text { firm. (R) }\end{array}$ \\
\hline $\begin{array}{l}\text { 3. We never experience a lack of ideas that } \\
\text { we can convert into profitable products/ } \\
\text { services. }\end{array}$ & 1 & 2 & 3 & 4 & 5 & 6 & 7 & 8 & 9 & 10 & $\begin{array}{l}\text { It is difficult for our firm to find ideas that } \\
\text { can be converted into profitable products/ } \\
\text { services. (R) }\end{array}$ \\
\hline
\end{tabular}

Table 3 Test on post buy-out increase in entrepreneurial management

\begin{tabular}{lcccc}
\hline & Mean & $\begin{array}{l}\text { Mean } \\
\text { difference }\end{array}$ & $T$ value & $P$ value \\
\hline $\begin{array}{l}\text { Dimension } \\
\text { Strategic orientation }\end{array}$ & 6.92 & 1.42 & 7.60 & $<0.00$ \\
Resource orientation & 5.81 & 0.31 & 2.03 & $<0.05$ \\
Management structure & 5.62 & 0.12 & 0.76 & $\mathrm{~ns}$ \\
Reward philosophy & 6.36 & 0.86 & 6.02 & $<0.00$ \\
Growth orientation & 6.07 & 0.57 & 2.87 & $<0.01$ \\
Entrepreneurial culture & 4.50 & -1.00 & -5.57 & $<0.00$ \\
$\begin{array}{l}\text { Overall model } \\
\text { Post MBO increase in entrepreneurial } \\
\text { management }\end{array}$ & 6.10 & 0.60 & 5.58 & $<0.00$ \\
$N=108$ & & & & \\
\hline
\end{tabular}

before a divisional (Meuleman et al. 2009) or family (Scholes et al. 2010) buyout.

\section{Results}

Table 4 presents correlations, means, and standard deviations relating to our variables. The correlations between the independent variables are relatively low $(|r|<0.37)$ which indicates that multicollinearity may not be a significant problem in our study. To further examine multicollinearity, we calculated variance inflation factors (VIF) for each regression equation between the independent variables. The maximum VIF score was 1.72, which is well below the cut-off of 10 suggested in the literature (Neter et al. 1990).

To test our three hypotheses, we estimated a hierarchical regression model; the estimation results are presented in Table 5. Model 1 contains only the control variables and subsequently each model adds an ownership variable to the model. To test our hypotheses we use the results of Model 4 in Table 5.

The $R^{2}$ is 0.37 which indicates that the model can explain $37 \%$ of the variance of post buyout increase in entrepreneurial management. Model 4 in Table 5 shows that increased financial leverage negatively affects entrepreneurial management $(\beta=-0.41$; $P<0.01)$ and PE majority ownership positively affects entrepreneurial management $(\beta=0.26 ; P<$ $.05)$. These findings support hypotheses $\mathrm{H} 1$ and $\mathrm{H} 2$. Furthermore we found no significant correlation between majority PE ownership and financial leverage (Table 4). Yet, the effect of the interaction between majority PE ownership and financial leverage on entrepreneurial management is negative and significant $(\beta=-0.22 ; P<0.05)$, which supports hypothesis H3 that PE majority ownership increases the opposite of entrepreneurial management, namely administrative management, if financial leverage is very high. Administrative management under conditions of very high financial leverage may help to reduce the debt level of the firm. Thus, overall the evidence supports the notion that PE firms stimulate entrepreneurial management in buyout firms but also administrative management in cases of very high levels of financial leverage.

We performed several robustness checks. First, because of the possibility of recall bias, we conducted estimates using different time frames and compared the results for early MBOs (1996-2000) with those for 
Table 4 Means, standard deviations, and correlations of all variables

\begin{tabular}{|c|c|c|c|c|c|c|c|c|c|c|c|c|c|}
\hline & Mean & SD & (1) & (2) & (3) & (4) & (5) & (6) & (7) & (8) & (9) & (10) & (11) \\
\hline Industry: trade (1) & 0.28 & 0.45 & 1 & & & & & & & & & & \\
\hline Industry: manufacturing (2) & 0.26 & 0.44 & -0.37 & 1 & & & & & & & & & \\
\hline Industry: services (3) & 0.20 & 0.41 & -0.31 & 0.30 & 1 & & & & & & & & \\
\hline Firm size (4) & 5.99 & 2.46 & -0.06 & 0.02 & -0.17 & 1 & & & & & & & \\
\hline Deal price $(5)$ & 2.52 & 0.98 & 0.07 & -0.11 & -0.10 & 0.05 & 1 & & & & & & \\
\hline Duration (6) & 3.81 & 2.49 & 0.01 & -0.05 & 0.10 & 0.03 & 0.07 & 1 & & & & & \\
\hline Debt ratio post-MBO (7) & 3.20 & 1.37 & -0.01 & 0.14 & -0.19 & 0.26 & -0.02 & 0.00 & 1 & & & & \\
\hline Majority PE ownership (8) & 0.43 & 0.47 & -0.14 & 0.14 & -0.03 & 0.00 & -0.22 & -0.18 & -0.11 & 1 & & & \\
\hline $\begin{array}{l}\text { Post-MBO increase } \\
\text { in entrepreneurial } \\
\text { management (9) }\end{array}$ & 6.10 & 0.84 & 0.07 & -0.22 & 0.03 & -0.04 & 0.04 & 0.12 & -0.40 & 0.25 & 1 & & \\
\hline
\end{tabular}

Correlations significant at the 0.05 level (two-tailed) are given in bold

Table 5 Results from hierarchical regression analysis of the post-MBO increase in entrepreneurial management

\begin{tabular}{|c|c|c|c|c|c|}
\hline \multirow[t]{13}{*}{ theng } & Industry: trade & 0.05 & -0.37 & -0.36 & -0.41 \\
\hline & Industry: services & -0.33 & 1.05 & 0.99 & 1.13 \\
\hline & Firm size & -0.10 & $-0.17 \dagger$ & $-0.17 \dagger$ & -0.17 \\
\hline & Duration & 0.13 & $0.15 \dagger$ & $0.18 \dagger$ & $0.23 \dagger$ \\
\hline & Deal price & -0.02 & -0.04 & 0.03 & 0.03 \\
\hline & Divisional/family buyout & -0.12 & $-0.17 \dagger$ & -0.12 & -0.10 \\
\hline & Lambda & -0.85 & 3.42 & 3.30 & 3.84 \\
\hline & Ownership attributes & & & & \\
\hline & Majority PE (H1) & & & $0.26^{*}$ & $0.26 * *$ \\
\hline & Financial Leverage (H2) & & $-0.45 * * *$ & $-0.42 * * *$ & $-0.41 * * *$ \\
\hline & Majority PE x financial leverage $(\mathrm{H} 3)$ & & & & $-0.22 *$ \\
\hline & $\mathrm{R} 2$ & 0.09 & $0.27 * * *$ & $0.32 * * *$ & $0.37 * * *$ \\
\hline & $\Delta \mathrm{R} 2$ (Model 1) & & $0.18 * * *$ & $0.23 * * *$ & $0.26 * * *$ \\
\hline \multirow{2}{*}{$\begin{array}{l}\dagger P<0.10, * P<0.05 \\
* * P<0.01 \\
* * * P<0.001\end{array}$} & $\Delta \mathrm{R} 2$ (Model 2) & & & $0.05 * *$ & $0.10 * *$ \\
\hline & $\Delta \mathrm{R} 2$ (Model 3) & & & & $0.05^{*}$ \\
\hline
\end{tabular}

late MBOs (2000-2004). Subsequently, we compared regressions for PE and non PE-backed buyouts separately. The results are robust between timeframes and financial leverage has a much more negative effect on entrepreneurial management for majority PEbacked firms than for other buyout firms. The difference in the coefficients is significant at the $P<0.001$ level. This supports the results from the hierarchical regression analysis. However, the coefficient for financial leverage for minority PE and non-PE-backed firms is only weakly significant at the $P<0.10$ level. Given the sample size limitations of our study, we conclude that further research is needed to establish if financial leverage has a negative effect on entrepreneurial management for minority and non-PE-backed firms. With regard to the control variables, the manufacturing industry variable shows lower levels of entrepreneurship, whereas the duration variable, 
measured as the number of years since the buyout, shows a weakly positive effect $(\beta=0.21, P<0.10)$ on entrepreneurship post buyout.

\section{Discussion}

Extending limited previous research on the effects of majority PE-backed versus other buy-outs on entrepreneurial activity, the results of our study show that entrepreneurial management increases after the buyout. Four of the six dimensions move toward the entrepreneurial mode of management: strategic orientation, reward philosophy, resource-orientation, and growth-orientation. The largest increase we observe is in strategic orientation and reward philosophy, which means that the business strategy of the firm is more driven by the perception and pursuit of valuable opportunities, irrespective of the firm's owned or controlled resources, and that post-buyout managers and employees are evaluated on the contribution to the value they add to the firm. However, two dimensions of entrepreneurial management behave differently; the management structure shows no significant change post buyout and the entrepreneurial culture moves in the opposite direction of the entrepreneurial management scale, specifically to the administrative management focus. Buyout firms develop an administrative focus in their culture, showing that controlled resources seem to be the starting point for taking into consideration ideas about opportunities. This contrasts with the outcome of the four dimensions that attach more importance to entrepreneurial management in dealing with opportunities, the availability of resources, value creation, and growth.

Furthermore, the findings suggest that MBOs with a majority PE position positively affect entrepreneurial management whereas increased leverage increases administrative management, which encompasses both opportunity-seeking behavior and advantage seeking behavior. To successfully meet future customer needs requires cognitive refocusing of CEOs and entrepreneurial changes in strategic, resource, and growth orientation. Our findings are supported by Ireland and Webb (2009), who discuss the transition between entrepreneurial and administrative management in terms of exploration and exploitation as a vital part of strategic entrepreneurship. Our study indicates that PE firms are important in this transition. Having a very different organizational cognitive focus, PE firms can help buy-out firms to develop and implement a new entrepreneurial view on their business. Future research could examine the role of PE firms in developing such ambidextrous entrepreneurial and administrative management practices in the transition process of MBOs, and whether minority and majority PE investors develop different skills for this process.

Our findings have implications for practitioners and policy makers. Our results contradict some of the criticisms of regulatory authorities, some politicians, and trade unions regarding the effect of PE and buyouts. According to the CEOs of the buyouts we studied, PE firms do not reduce the chances of bought out firms initiating and sustaining entrepreneurial management. Further, PE firms may exercise administrative management to manage the debt level if the buy-outs involve very high leverage. In this study PE can be regarded as an ambidextrous financier: they stimulate entrepreneurial management to create more economic value and at the same time facilitate administrative management in order to reduce the risks of high leverage. Our findings from buy-outs suggest that the development of broad-based restrictions on majority PE-backed buy-outs may have detrimental effects on entrepreneurial growth of companies. If policy makers with concerns about PE buy-outs seek to tighten their regulation, a more detailed approach may be needed. With regard to practitioners, the extent of entrepreneurial management we have identified suggests the need for careful attention both to the skills available in buy-out teams and the expertise in PE firms, so that financial investors can best add value to their portfolio companies. More specifically, MBOs run a higher rather than a lower risk if high leverage is not mitigated by active PE portfolio administrative management. Our finding regarding the importance of duration of time indicates that firms may need time to develop entrepreneurial management after the buyout. This suggests that practitioners and policy makers may need to be careful not to adopt a short-term approach by only focusing upon the changes that happen around and shortly after the buyout.

As with all studies, ours has a number of limitations that introduce possibilities for further research. We have focused on the effects of buyouts on entrepreneurial and administrative management in these firms but how this compares with the different vendor 
sources of buy-outs is not clear. Future research with larger datasets could look at differences and similarities between buyouts from divested parts of companies, of family buyouts, public to private buy-outs, management buy-ins, or secondary buy-outs.

The study focused on the perspective of entrepreneurial and administrative management as seen by CEOs involved in leading the buy-out or buy-in or the private equity backed buy-out firm. The selected key informants are CEOs who had been involved in negotiating and implementing the buyouts and they possessed the detailed information requested. Fresh insights relating to the entrepreneurial and administrative management process may be provided when several of those involved in the process are consistently contacted over time. For example, the perspectives of former family owners, non-family managers, PE providers, and independent consultants could be compared to ensure that valid and reliable evidence is collected.

Although we have examined the extent of PE ownership, we were unable to directly explore further the effect of specific expertise and experience of different PE firms on entrepreneurial and administrative management and performance. We did collect data on the number of executive investors and capital managed/advised of PE firms and use this ratio as proxy of the intensity of monitoring. However, neither variable was significant and, therefore, we excluded these variables from the analysis. This is, however, an important area for further research that can lead to more insight, for example, regarding whether different fund management teams in PE firms use different monitoring intensity to stimulate entrepreneurial and or administrative management of the company in which they are investing. We have identified an initial indication of the importance of buyout duration on the emergence of entrepreneurial management but more detailed analysis is needed to examine whether this particularly applies to the more sticky dimensions of entrepreneurial management dimensions, for example structure and entrepreneurial culture. This finding may also have implications for the investment time horizon adopted by the particular PE investor, and this must be investigated in future research.

This study has drawn upon a unique, representative sample of the population of buyouts in the Netherlands. Further research might be carried out in other countries to ascertain whether the findings for institutions in the Netherlands are also valid for markets working in different institutional environments, for example the French civil code, emerging markets in South America and Asia, and underdeveloped regions. Such research would add to understanding of whether PE buy-outs and their effects are universal phenomena or dependent upon institutional conditions.

Although the sample was relatively small, it was representative of the population with regard to industry sector and firm size. Further research might usefully seek to expand the dataset to encompass a larger sample. Future research may incorporate longitudinal studies, which could usefully highlight any additional ownership and governance changes in the life cycle of the firm and any ensuing effect on entrepreneurial and administrative management. Given the size of the sample, clustering involving $\mathrm{PE}$ investing in multiple firms in the sample was a possibility. Our check indicated that this was unlikely to be a problem and could be expected to be the case, because across the size ranges of buyouts covered by this study, which covers a vast number of deals, there are many PE investors in the open economy of the Netherlands (EVCA Directory 2006).

\section{Conclusions}

Using a unique, representative, and focused sample completed during the recent second wave of buy-outs in the Netherlands, this study sought to shed light on recent criticisms of the effect of $\mathrm{PE}$ firms on the companies in which they invest. On the basis of a theoretically grounded reconceptualization of the PE firm as a cognitive refocusing device for buy-out firms, we find evidence that majority PE-backed buy-outs are associated with significant increases in both entrepreneurial and administrative management practices. We also find evidence that PE-backed buy-outs increase the effect of financial leverage on administrative management in cases of high leverage. Our analysis extends the limited research that has pointed to growth and entrepreneurship after PE-backed buy-outs and provides a more nuanced picture regarding their role in the development of entrepreneurial and administrative management.

Acknowledgment The authors would like to thank Linna Chang en Gordon White for their research assistance and two anonymous reviewers for their valuable comments. 
Open Access This article is distributed under the terms of the Creative Commons Attribution Noncommercial License which permits any noncommercial use, distribution, and reproduction in any medium, provided the original author(s) and source are credited.

\section{References}

Acharya, V. V., Franks, J., \& Servaes, H. (2007). PE: Boom and bust? Journal of Applied Corporate Finance, 19(4), 44-53.

Andrade, G., \& Kaplan, S. N. (1998). How costly is financial (not economic) distress? Evidence from highly leveraged transactions that became distressed. Journal of Finance, 53(5), 1443-1493.

Armstrong, J., \& Overton, T. (1977). Estimating non-response bias in mail surveys. Journal of Marketing Research, 14(3), 396-402.

Berger, A. N., \& Bonaccorsi di Patti, E. (2006). Capital structure and firm performance: A new approach to testing agency theory and an application to the banking industry. Journal of Banking and Finance, 30(4), 1065-1102.

Brown, T. E., Davidsson, P., \& Wiklund, J. (2001). An operationalization of Stevenson's conceptualization of entrepreneurship as opportunity-based firm behavior. Strategic Management Journal, 22(10), 953-968.

Bruining, H., Bonnet, M. P. B., \& Wright, M. (2004). Management control systems and strategy change in buyouts. Management Accounting Research, 15, 155-177.

Bruining, H., \& Wright, M. (2002). Entrepreneurial orientation in management buyouts and the contribution of venture capital. Venture Capital: An International Journal of Entrepreneurial Finance, 4(2), 147-168.

Bull, I. (1989). Management performance in leveraged buyouts: An empirical analysis. In Y. Amihud (Ed.), Leveraged management buyouts, causes and consequence (pp. 6994). Illinois: Dow Jones-Irwin.

Campello, M. (2003). Capital structure and product markets interactions: Evidence from business cycles. Journal of Financial Economics, 68, 353-378.

Cotter, J. F., \& Peck, S. W. (2001). The structure of debt and active equity investors: The case of the buy-out specialist. Journal of Financial Economics, 59, 101-147.

Cressy, R., Malipiero, A., \& Munari, F. (2007). Playing to their strengths? Evidence that specialization in the PE industry confers competitive advantage. Journal of Corporate Finance, 13, 647-669.

Cumming, D., Siegel, D. S., \& Wright, M. (2007). PE, leveraged buyouts and governance. Journal of Corporate Finance, 13, 439-460.

Desbrières, P., \& Schatt, A. (2002). The impacts of LBOs on the performance of acquired firms: The French case. Journal of Business Finance and Accounting, 29, 695-729.

Easterwood, J. C., Seth, A., \& Singer, R. F. (1989). The impact of leveraged buyouts on strategic direction. California Management Review, 32(1), 30-43.

EVCA. (2006). Directory of the European private equity and Venture Capital Association, Brussels, June 2006.
Financial Services Authority. (2006). PE: A discussion of risk and regulatory engagement. Discussion Paper DP06/6. London: Financial Services Authority.

Glick, W. H. (1985). Conceptualizing and measuring organizational and psychological climate: Pitfalls in multilevel research. Academy of Management Review, 10(3), 601616.

Green, S. (1992). The impact of ownership and capital structure on managerial motivation and strategy in management buy-outs: A cultural analysis. Journal of Management Studies, 4, 513-535.

Halpern, P., Kieschnick, R., \& Rotenberg, W. (1999). On the heterogeneity of leveraged going private transactions. Review of Financial Studies, 12, 281-309.

Harris, R., Siegel, D., \& Wright, M. (2005). Assessing the impact of management buyouts on economic efficiency: Plant-level evidence from the United Kingdom. Review of Economics and Statistics, 87, 148-153.

Hite, G. L., \& Vetsuypens, M. (1989). Management buyouts of divisions and shareholder wealth. The Journal of Finance, 44(4), 953-970.

Ireland, R. D., \& Webb, J. W. (2009). Crossing the great divide of strategic entrepreneurship: Transitioning between exploration and exploitation. Business Horizons, 52, 469-479.

James, L.R., R.G. Demaree, \& Wolf, G. (1993). Rwg: An assessment of within-group interrater agreement. Journal of Applied Psychology.78(2) 306-309.

Jensen, M. C. (1986). Agency costs of free cash flow, corporate finance and takeover. American Economic Review Papers and Proceedings, 76, 323-329.

Jensen, M. C. (1989). Eclipse of the public corporation. Harvard Business Review, 67(5), 61-74.

Jensen, M. C. (1993). The modern industrial revolution, exit and the failure of internal control systems. Journal of Finance, 48, 831-880.

Jensen, M. C., Kaplan S. (2006). Morgan Stanley roundtable on $\mathrm{PE}$ and its import for public companies. Journal of Applied Corporate Finance 3(18), 8-37.

Jones, C. S. (1992). The attitudes of owner-managers towards accounting control systems following management buyout. Accounting Organizations and Society, 17(2), 151-168.

Kaplan, S. (1989). The effects of management buyouts on operating performance and value. Journal of Financial Economics, 24, 217-254.

Kaplan, S. N., \& Strömberg, P. (2009). Leveraged buyouts and PE. Journal of Economic Perspectives, 23(1), 121-146.

Lerner, J., Strömberg, P., Sørensen, M. (2008). PE and long-run investment: The case of innovation. In J. Lerner \& A. Gurung (Eds.). The Global Impact of PE Report 2008, Globalization of Alternative Investments, Working Papers Volume 1, World Economic Forum (pp. 27-42).

Lichtenberg, F. R., \& Siegel, D. (1990). The effects of leveraged buyouts on productivity and related aspects of firm behavior. Journal of Financial Economics, 27, 165-194.

Long, W. F., \& Ravenscraft, D. J. (1993). LBOs, debt and R\&D intensity. Strategic Management Journal (Summer Special Issue), 14, 119-135.

March, J. G. (1988). Variable risk preferences and adaptive aspirations. Journal of Economic Behavior and Organization, 10, 143-171. 
March, J. G. (1991). Exploration and exploitation in organizational learning. Organizational Science, 2, 71-87.

Meuleman, M., Amess, K., Wright, M., \& Scholes, L. (2009). Agency, strategic entrepreneurship, and the performance of PE-backed buyouts. Entrepreneurship, Theory and Practice, 33(1), 213-239.

Neter, J., Wasserman, W., \& Kutner, M. H. (1990). Applied linear statistical models. Homewood: Irwin.

Nikoskelainen, E., \& Wright, M. (2007). The impact of corporate governance mechanisms on value increase in leveraged buyouts. Journal of Corporate Finance, 13, 511-537.

Nooteboom, B. (2009). A cognitive theory of the firm. Learning, governance and dynamic capabilities. Cheltenham: Edwar Elgar Publishing.

Opler, T., \& Titman, S. (1993). The determinants of leveraged buyout activity: Free cash flow vs financial distress costs. Journal of Finance, 48(5), 1985-1999.

Phan, P., \& Hill, C. (1995). Organizational restructuring and economic performance in leveraged buyouts: An ex post study. Academy of Management Journal, 38(3), 704-773.

PSE Socialist Group in the European Parliament (2007). Hedge Funds and PE-A Critical Analysis. Report of the PSEGroup in European Parliament.

Rappaport, A. (1990). The staying power of the public corporation. Harvard Business Review, 68, 96-104.

Reid, G. C. (1996). Fast growing small entrepreneurial firms and their venture capital backers: An applied principal-agent analysis. Small Business Economics, 8, 1-14.

Renneboog, L., Simons, T., \& Wright, M. (2007). Why do firms go private in the UK? Journal of Corporate Finance, 13, 591-628.

Robbie, K., \& Wright, M. (1995). Managerial and ownership succession and corporate restructuring: The case of management buy-ins. Journal of Management Studies, 32, $527-550$.

Robbie, K., \& Wright, M. (1996). Management buy-ins: Entrepreneurship, active investors and corporate restructuring. Manchester: MUP.

Robbie, K., Wright, M., \& Ennew, C. (1993). Management buyouts from receivership. Omega, 21, 519-530.

Scholes, L., Wright, M., Westhead, P., Bruining, H. (2010). The effect of ownership and governance on the strategy of family firms: Evidence of management buy-outs. International Small Business Journal. doi:10.1177/0266242610 370390.

Singh, H. (1990). Management buyouts: Distinguishing characteristics and operating changes prior to public offering. Strategic Management Journal, Special issue: Corporate Entrepreneurship, 11, 111-129.

Smith, A. J. (1990). Corporate ownership structure and performance: The case of management buyouts. Journal of Financial Economics, 27, 143-164.
Stevenson H. H. (1983). A perspective on entrepreneurship. Harvard Business School, Working Paper 9-384-131.

Stevenson, H. H., \& Gumpert, D. (1985). The heart of entrepreneurship. Harvard Business Review, 63, 85-94.

Weir, C., Laing, D., \& Wright, M. (2005). Incentive effects, monitoring mechanisms and the market for corporate control: An analysis of the factors affecting public to private transactions in the UK. Journal of Business Finance and Accounting, 32, 909-944.

Wiersema, M. and Liebeskind, J. (1995). The Effects of Leveraged Buyouts on Corporate Growth and Diversification within Large Firms. Strategic Management Journal, 16, 447-460.

Williamson, O. E. (1991). Comparative economic organization: The examination of discrete structural alternatives. Administrative Science Quarterly, 36, 269-296.

Wright, M., \& Bruining, H. (2008). PE and management buyouts: International trends, evidence and policy implications. In M. Wright \& H. Bruining (Eds.), Private equity and management buy-outs (pp. 3-78). Cheltenham: Edward Elgar Publishing Limited.

Wright, M., Chiplin, B., Thompson, S., \& Robbie, K. (1990). Management buyouts and large-small firm relationships. Management International Review, 30, 55-72.

Wright, M., Hoskisson, R. E., \& Busenitz, L. (2001a). Firm rebirth: Buyouts as facilitators of strategic growth and entrepreneurship. The Academy of Management Executive, 15(1), 111-125.

Wright, M., Hoskisson, R. E., Busenitz, L. W., \& Dial, J. (2000). Entrepreneurial growth through privatization: The upside of management buyouts. The Academy of Management Review, 25(3), 591-601.

Wright, M., Hoskisson, R. E., Busenitz, L., \& Dial, J. (2001b). Finance and management buy-outs: Agency versus entrepreneurship perspectives. Venture Capital: An International Journal of Entrepreneurial Finance, 3(3), 239-261.

Wright, M., Robbie, K., Thompson, S., \& Starkey, K. (1994). Longevity and the life-cycle of MBOs. Strategic Management Journal, 15(3), 215-227.

Wright, M., Thompson, S., Chiplin, B., \& Robbie, K. (1991). Buy-ins and buy-outs, new strategies in corporate management. London/Dordrecht/Boston: International Management Series, Graham and Trotman.

Wright, M., Thompson, S., \& Robbie, K. (1992). Venture capital and management led leveraged buyouts: The European perspective. Journal of Business Venturing, 7, 47-71.

Zahra, S. A. (1995). Corporate entrepreneurship and financial performance: The case of management leveraged buyouts. Journal of Business Venturing, 10, 225-247. 